\title{
Pengaruh Gender, Penghargaan Finansial dan Pertimbangan Pasar Kerja terhadap Minat Berkarir menjadi Akuntan Publik pada Mahasiswa Akuntansi Sekolah Tinggi Ilmu Ekonomi Balikpapan
}

\author{
Fice Handayani \\ STIE Balikpapan (STIEPAN), Balikpapan \\ Email: ficehandayani80@gmail.com
}

\begin{abstract}
This study aims to prove whether gender, financial rewards and labor market considerations affect career interest in becoming a public accountant for accounting students at the Balikpapan College of Economics.The analytical tool used in this research is Multiple Linear Regression. Financial rewards and labor market considerations affect career interest in becoming a public accountant for accounting students at the Balikpapan College of Economics, and among the two variables the most dominant is financial rewards with a higher tcount value. greater than the value of t table (2.908> 1.992). and the sig value. $0.005<0.05$. For the gender variable, it shows that there is no influence on the interest in a career as a public accountant for accounting students at the Balikpapan College of Economics, where the results show that tcount (-1.199) is smaller than t table (1.992) with a sig value. 0.234 is greater than the specified significance of 0.05 .
\end{abstract}

Keywords: gender, financial rewards, labor market, public accountant

\begin{abstract}
Abstrak
Penelitian ini bertujuan untuk membuktikan apakah gender, penghargaan finansial dan pertimbangan pasar kerja berpengaruh terhadap minat berkarir menjadi akuntan publik pada mahasiswa akuntansi Sekolah Tinggi Ilmu Ekonomi Balikpapan. Alat analisis yang dipergunakan dalam penelitian ini adalah Regresi Linear Berganda. Penghargaan finansial dan pertimbangan pasar kerja berpengaruh terhadap minat berkarir menjadi akuntan publik pada mahasiswa akuntansi Sekolah Tinggi Ilmu Ekonomi Balikpapan, dan diantara kedua variabel tersebut yang paling dominan adalah penghargaan finansial dengan nilai $t_{\text {hitung }}$ lebih besar dari niai $t_{\text {tabel }}(2,908>1,992)$ dan nilai sig. $0,005<0,05$. Untuk variabel gender menunjukan tidak adanya pengaruh terhadap minat berkarir menjadi akuntan publik pada mahasiswa akuntansi Sekolah Tinggi Ilmu Ekonomi Balikpapan, dimana hasilnya menunjukkan $t$ hitug $(-1,199)$ lebih kecil dari t tabel $(1,992)$ dengan nilai sig. 0,234 lebih besar dari siginifikan yang di tetapkan yakni 0,05 .
\end{abstract}

Kata kunci: gender, penghargaan finansial, pasar kerja, akunta publik.

\section{Pendahuluan}

Profesi akuntan publik merupakan profesi yang sangat dibutuhkan dalam dunia bisnis untuk dapat menjaga dan meningkatkan kualitas informasi keuangan, karena informasi keuangan yang berkualitas akan memiliki dampak yang dibutuhkan oleh para pemangku kepentingan. Profesi ini memberikan peluang untuk mendapatkan pekerjaan yang menantang dan bervariasi karena dapat ditugaskan diberbagai tempat dan perusahaan yang memiliki ciri dan kondisi yang berbeda. Profesi akuntan publik di Indonesia juga termasuk profesi yang prestisius karena selain harus mempunyai gelar sarjana akuntansi, calon akuntan diharuskan mengikuti ujian sertifikasi yang diselenggarakan oleh Ikatan Akuntan Indonesia (IAI) dan terdaftar di Departemen Keuangan untuk bisa berpraktek sebagai seorang akuntan.

Minat mahasiswa akuntansi untuk berkarir menjadi akuntan publik saat ini tergolong masih rendah. Rendahnya minat mahasiswa akuntansi untuk berkarir menjadi akuntan publik salah satunya disebabkan oleh proses yang harus dilalui untuk menjadi seorang akuntan publik yang tidaklah mudah, dimulai dari mahasiswa akuntansi harus menempuh pendidikan S1 akuntansinya yang memerlukan waktu antara 3-7 tahun hingga dinyatakan lulus dan menjadi 
seorang sarjana akuntansi, kemudian dilanjutkan dengan mengikuti Pendidikan Profesi Akuntansi (PPA) yang diperlukan waktu antara 9 sampai dengan 24 bulan serta mengikuti ujian Certified Public Accountant (CPA). Mereka akan mendapatkan gelar sebagai akuntan setelah menyelesaikan PPA dan kemudian mengajukan izin ke Kementrian Keuangan untuk mendapatkan nomor register yang membutuhkan waktu 3 sampai dengan 4 bulan sejak lulus dari pendidikan profesi..

Sekolah Tinggi Ilmu Ekonomi Balikpapan (STIEPAN) merupakan Sekolah Tinggi Ilmu Ekonomi yang tertua di Balikpapan yang terdiri dari dua Program Studi yakni Akuntansi dan Manajemen. Sejak berdiri pada tahun 1983 silam STIE Balikpapan (STIEPAN) hadir sebagai kampus pencetak sarjana-sarjana ekonomi yang berkualitas dan terserap di dunia kerja serta aktif dalam berperan dalam pembangunan di Kalimantan Timur khususnya di Kota Balikpapan. STIEPAN kini telah memiliki dua kampus yang berada di dua lokasi yang berbeda yaitu kampus satu yang beralamat di Perkampungan Pelajar Gunung Pasir dan kampus dua yang beralamat di jalan Mayor Pol. Zainal Arifin NO.166 RT. 48 Sumber Rejo Balikpapan Tengah. STIEPAN memiliki dua Program Studi yaitu Program Studi Akuntansi dan Manajemen yang mana keduanya telah terakreditasi (B) oleh BAN-PT, selain itu STIEPAN juga memiliki beberapa program unggulan yang berpotensi mendukung gelar sarjana Ekonomi yaitu porgram Brevet Pajak A\&B. Setelah dilakukan wawancara kepada beberapa mahasiswa STIEPAN ternyata minat untuk menjadi akuntan publik setelah lulus sarjana akuntansi masih tergolong rendah. Kurangnya minat mahasiswa dan mahasiswi ini karena tidak diadakannya penjurusan bagi para mahasiswa akuntansi di STIEPAN. Tidak adanya penjurusan serta fasilitas yang dapat menunjang untuk mengembangkan karir membuat para mahasiswa akuntansi cenderung belum memikirkan secara serius sejak masih duduk dibangku kuliah mengenai karir apa yang diinginkan dan akan dijalaninya kelak di masa depan. Dan juga disebabkan oleh keadaan para mahasiswa yang sebagian besar telah bekerja.

Minat mahasiswa akuntansi untuk berkarir menjadi akuntan publik ini di pengaruhi oleh beberapa faktor, diantaranya faktor gender, penghargaan finansial dan pertimbangan pasar. Dan penelitian-penelitian sebelumnya yang relevan yang membahas faktor-faktor ini sudah banyak dilakukan namun hasilnya berbeda- beda. Dewayani, et al (2017), mengatakan bahwa gender berpengaruh terhadap minat mahasiswa akuntansi dalam pemilihan profesi sebagai akuntan publik namun hasil ini tidak sejalan dengan Suseno (2019) yang menyatakan bahwa variabel gender tidak berpengaruh terhadap minat mahasiswa akuntansi untuk memutuskan memilih akuntan publik sebagai profesinya. Trista (2016), hasil penelitiannya menyatakan bahwa penghargaan finansial tidak berpengaruh terhadap minat mahasiswa akuntansi dalam pemilihan akuntan publik sebagai profesinya dan hasil ini tidak sejalan dengan penelitian yang dilakukan oleh Dewayani, et al (2017) dan Febriyanti (2019) yang menyatakan bahwa penghargaan finansial merupakan salah satu variabel yang berpengaruh terhadap minat mahasiswa akuntansi dalam memutuskan akuntan publik sebagai suatu profesi. Karena adanya perbedaan hasil penelitian dari peneliti terdahulu ini membuat peneliti tertarik untuk melakukan penelitian kembali supaya mendapatkan hasil yang lebih baik. Berdasarkan latar belakang yang telah dijelaskan diatas, maka rumusan masalah dalam penelitian ini adalah:

1) Apakah gender berpengaruh terhadap minat mahasiswa akuntansi Sekolah Tinggi Ilmu Ekonomi Balikpapan berkarir menjadi akuntan publik.

2) Apakah penghargaan finansial berpengaruh terhadap minat mahasiswa akuntansi Sekolah Tinggi Ilmu Ekonomi Balikpapan berkarir menjadi akuntan publik

3) Apakah pertimbangan pasar kerja berpengaruh terhadap minat mahasiswa akuntansi Sekolah Tinggi Ilmu Ekonomi Balikpapan berkarir menjadi akuntan publik 


\subsection{Pengaruh Gender Terhadap Minat Mahasiswa Akuntansi Sekolah Tinggi Ilmu Ekonomi Balikpapan Berkarir Menjadi Akuntan Publik}

Menurut Nurhayati (2011:133) menjelaskan bahwa "Gender adalah suatu konstuksi sosial yang mengatur hubungan perempuan dan laki-laki yang terbentuk melalui proses sosialisasi”. "Gender" dapat diartikan sebagai perbedaan peran, fungsi, status, dan tanggung jawab pada laki-laki dan perempuan yang merupakan hasil konstruksi sosial budaya yang tertanam lewat proses sosialisasi didalam masyarakat, dengan kata lain gender merupakan hasil kesepakatan antara manusia yang tidak bersifat kodrati, sehingga dapat berubah sesuai dengan situasi sosial budaya dan nilai didalam masyarakat..Menurut Puspitawati (2019:60), "Gender adalah perbedaan antara laki-laki dan perempuan dalam peran, fungsi, hak, tanggung jawab, dan perilaku yang dibentuk oleh tata nilai sosial, budaya adat istiadat dari kelompok masyarakat yang dapat berubah menurut waktu dan kondisi masyarakat setempat". Hasil penelitian Dewayani, et al ( 2017) dan Saputra (2018), bahwa gender berpengaruh terhadap minat mahasiswa akuntansi dalam pemilihan akuntan publik sebagai suatu profesi. Berdasarkan penjelasan tersebut diatas maka dapat ditarik hipotesis sebagai berikut :

H1 : Bahwa gender berpengaruh terhadap minat mahasiswa akuntansi Sekolah Tinggi Ilmu Ekonomi Balikpapan berkarir menjadi akuntan publik.

\subsection{Pengaruh Penghargaan Finansial Terhadap Minat Mahasiswa Akuntansi Sekolah Tinggi Ilmu Ekonomi Balikpapan Berkarir Menjadi Akuntan Publik}

Rivai (2011:358) mendefinisikan bahwa "Penghargaan finansial sebagai balas jasa dalam bentuk uang yang diterima karyawan karena telah memberi kontribusi dalam kedudukannya di perusahaan untuk mencapai tujuan perusahaan". Hasil penelitian Febriyanti (2019), menunjukkan bahwa penghargaan finansial berpengaruh terhadap minat mahasiswa dalam pemilihan karir sebagai akuntan publik, dimana sampel yang diambil sebanyak 129 mahasiswa S1 Akuntansi Universitas Serang Raya. Dewayani, et al (2017) juga membuktikan bahwa penghargaan finansial berpengaruh terhadap pemilihan karir sebagai akuntan publik dengan sampel mahasiswa Prodi Akuntansi Universitas Muhammadiyah Magelang. Sehingga berdasarkan penjelasan tersebut dapat ditarik hipotesis sebagai berikut :

H2 : Bahwa penghargaan finansial berpengaruh terhadap minat mahasiswa akuntansi Sekolah Tinggi Ilmu Ekonomi Balikpapan berkarir menjadi akuntan publik.

\subsection{Pengaruh Pertimbangan Pasar Kerja Terhadap Minat Mahasiswa Akuntansi \\ Sekolah Tinggi Ilmu Ekonomi Balikpapan Berkarir Menjadi Akuntan Publik}

Dalam pertimbangan pasar kerja ini tergantung dari seberapa mudah informasi yang dapat di akses oleh pencari kerja khususnya mahasiswa akuntansi tentang adanya lowongan pekerjaan sebagai akuntan publik. Dewayani, et al (2017) dan Oktaviani, et al (2020) didalam penelitiannya juga membuktikan bahwa pertimbangan pasar kerja berpengaruh terhadap pemilihan karir sebagai akuntan publik pada mahasiswa Program Studi Akuntansi. Dari penjelasan tersebut maka dapatlah ditarik hipotesis bahwa :

H3 : Bahwa pertimbangan pasar kerja berpengaruh terhadap minat mahasiswa akuntansi Sekolah Tinggi Ilmu Ekonomi Balikpapan berkarir menjadi akuntan publik.

\section{Metodologi}

Penelitian ini dilakukan di lingkungan Sekolah Tinggi Ilmu Ekonomi Balikpapan (STIEPAN) kampus dua yang beralamat di jalan Mayor Pol. Zainal Arifin NO.166 RT. 48 Sumber Rejo Balikpapan Tengah. Dan untuk populasi yang digunakan dalam penelitian ini adalah mahasiswa/i aktif Strata-1 Program studi Akuntansi Sekolah Tinggi Ilmu Ekonomi Balikpapan (STIEPAN) angkatan 2016 dan 2017. Alasan mengapa menggunakan populasi pada mahasiswa jurusan akuntansi angkatan 2016 dan 2017 adalah karena mereka merupakan mahasiswa yang sudah memasuki semester akhir dan akan segera menyelesaikan masa studinya sehingga dianggap telah memiliki rencana karir apa yang akan dipilihnya ketika lulus , total keseluruhannya ada 243 orang. Untuk sampel menggunakan teknik purposive sampling. 
Menurut Sugiyono (2018:85), "purposive sampling adalah teknik pengambilan sampel sumber data dengan pertimbangan tertentu." Oleh karena itu pertimbangan yang diambil dalam penelitian ini adalah :

a. Mahasiswa Prodi Akuntansi angkatan 2016 dan 2017 yang lulus mata kuliah Pengauditan 1 dan Pengauditan 2 dengan nilai minimal B

b. Mahasiswa Prodi Akuntansi angkatan 2016 dan 2017 yang lulus mata kuliah Akuntansi

Keuangan (Pengantar Akuntansi 1 \& 2, Akuntansi Keuangan Menengah 1 \& 2, Akuntansi

Keuangan Lanjutan $1 \& 2$ ) dengan nilai minimal B

c. Mahasiswa Prodi Akuntansi angkatan 2016 dan 2017 yang IPK nya diatas 3.

Penentuan sampel dalam teknik ini menggunakan rumus Slovin dengan rincian sebagai berikut (Gendro, 2011:78):

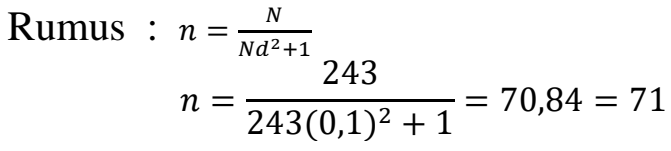

Keterangan :

$\mathrm{n}=$ Jumlah Sampel

$\mathrm{N}=$ Jumlah Populasi

$\mathrm{d}=$ Presentase tingkat ketelitian atau kesalahan yang diharapkan tidak menyimpang, $10 \%$.

Berdasarkan perhitungan menggunakan rumus tersebut, maka jumlah sampel dalam penelitian minimal berjumlah 71 responden mahasiswa/i jurusan akuntansi. Penarikan sampel yang dilakukan dengan menentukan nilai presisi (d) yang ditetapkan sebesar 10\%. Dan setelah dilakukan pendataan sesuai dengan pertimbangan dalam pengambilan sampel diatas maka didapatkanlah jumlah sampel yang sesuai sebanyak 79 responden. Dalam rangka untuk memperoleh data-data yang dibutuhkan dalam penelitian ini maka teknik pengumpulan data dilakukan dengan cara:

1. Kuisioner

Pengumpulan data dilakukan dengan cara menggunakan survey kuisioner online (https://forms.gle/pPTufcCgUmR4Q9C89) yang dibagikan kepada responden yaitu mahasiswa akuntansi STIEPAN. Instrumen penelitian ini adalah kuisioner dengan menggunakan skala Interval dengan lima alternatif jawaban yaitu: sangat tidak setuju, tidak setuju , ragu-ragu, setuju, dan sangat setuju.

2. Studi Kepustakaan

Yaitu pengumpulan data yang diperoleh dengan cara membaca literatur-literatur, jurnal dan sumber lainnya yang berhubungan dengan masalah penelitian.

Data di analisis dengan menggunakan Regresi Linear Berganda, dan juga melakukan uji kualitas data (uji instrument penelitian) dengan menggunakan uji validitas dan reabilitas. Sebelum melakukan analisis data dengan Regresi linear berganda terlebih dahulu dilakukan Uji Asumsi Klasik yakni merupakan pengujian yang digunakan dengan tujuan untuk memastikan bahwa data yang diperoleh akan dapat dianalisis dengan metode analisis regresi linear berganda. Uji asumsi klasik ini terdiri dari uji normalitas, uji multikolonearitas dan uji heteroskedastisitas.

\section{Hasil dan Pembahasan}

\subsection{Instrumen Penelitian}

Variabel dependen atau sering disebut variabel terikat adalah variabel yang dipengaruhi atau menjadi akibat dari adanya variabel independen atau variabel bebas. Variabel dependen dalam penelitian ini menggunakan skala likert. Skala likert adalah skala yang digunakan untuk mengukur sikap, pendapat dan persepsi seseorang ataupun sekelompok orang tentang suatu fenomena atau kejadian tertentu (Sugiyono, 2018:134).

Variabel dependen atau variabel terikat yang digunakan dalam penelitian ini adalah minat berkarir menjadi akuntan publik pada mahasiswa akuntansi (Y). Variabel ini diukur dengan mengggunakan skala likert dengan lima skala nilai (sangat tidak setuju, tidak setuju, ragu-ragu, setuju dan sangat setuju) dan diuji dengan 6 butir pertanyaan dengan indikator yang 
digunakan adalah: minat pribadi untuk menjadi akuntan publik,minat situasi untuk menjadi akuntan publik dan minat dalam ciri psikologi untuk menjadi akuntan publik.

Untuk variabel independen atau variabel bebas yakni gender $\left(\mathrm{X}_{1}\right)$, penghargaan finansial $\left(\mathrm{X}_{2}\right)$ dan pertimbangan pasar kerja $\left(\mathrm{X}_{3}\right)$ juga diukur dengan menggunakan skala likert dengan lima skala nilai (sangat tidak setuju, tidak setuju, ragu-ragu, setuju dan sangat setuju) dan diuji dengan 6 butir pertanyaan. Untuk lebih jelasnya dapat dilihat pada tabel 1 berikut:

Tabel 1. Instrumen Kuisioner

\begin{tabular}{|c|c|c|c|c|}
\hline No & Variabel & Indikator Pernyataan & Sumber & Skala \\
\hline 1. & $\begin{array}{l}\text { Minat Berkarir } \\
\text { menjadi Akuntan } \\
\text { Publik (Y) }\end{array}$ & $\begin{array}{l}\text { 1. Minat pribadi untuk menjadi } \\
\text { akuntan publik } \\
\text { 2. Minat situasi untuk menjadi } \\
\text { akuntan publik } \\
\text { 3. Minat dalam ciri psikologi } \\
\text { untuk menjadi akuntan publik }\end{array}$ & (Putro, 2012) & Likert \\
\hline 2. & Gender $\left(\mathrm{X}_{1}\right)$ & $\begin{array}{l}\text { 1. Hak dan kewajiban antara laki- } \\
\text { laki dan perempuan } \\
\text { 2. Perilaku dalam pengambilan } \\
\text { keputusan antara laki-laki dan } \\
\text { perempuan. } \\
\text { 3. Jaminan kenaikan jabatan di } \\
\text { masa depan antara laki-laki dan } \\
\text { perempuan. } \\
\text { 4. Ruang lingkup pekerjaan yang } \\
\text { terbatas antara laki-laki dan } \\
\text { perempuan } \\
\text { 5. Ketegasan dalam pengambilan } \\
\text { keputusan antara laki-laki dan } \\
\text { perempuan } \\
\text { 6. Pendekatan dalam } \\
\text { menyelesaikan masalah }\end{array}$ & (Suseno, 2019) & Likert \\
\hline 3. & $\begin{array}{l}\text { Penghargaan } \\
\text { Finansial }\left(\mathrm{X}_{2}\right)\end{array}$ & $\begin{array}{l}\text { 1. Penghasilan jangka panjang } \\
\text { yang bagus } \\
\text { 2. Gaji awal yang tinggi. } \\
\text { 3. Peluang standar hidup lebih } \\
\text { tinggi } \\
\text { 4. Adanya bonus atau insentif } \\
\text { lainnya } \\
\text { 5. Adanya dana pensiun. }\end{array}$ & (Trista, 2016) & Likert \\
\hline 4. & $\begin{array}{l}\text { Pertimbangan } \\
\text { Pasar Kerja }\left(\mathrm{X}_{3}\right)\end{array}$ & $\begin{array}{l}\text { 1. Keamanan kerja yang terjamin } \\
\text { 2. Ketersediaan lowongan kerja } \\
\text { yang mudah diakses } \\
\text { 3. Fleksibel dalam pemilihan karir } \\
\text { 4. Adanya variasi pekerjaan. }\end{array}$ & (Trista, 2016) & Likert \\
\hline
\end{tabular}

Analisis deskriptif dalam penelitian ini menggunakan nilai minimum, maksimum, ratarata (mean), dan standar deviasi atas jawaban responden yang diperoleh dari tiap-tiap variabel. Penelitian analisis statistik deskriptif ini memberikan penilaian tentang tinggi rendahnya minat berkarir sebagai akuntan publik terhadap keseluruhan variabel penelitian tersebut, hasil analisis deskriptif untuk masing-masing variabel penelitian dapat dilihat pada tabel 2 berikut: 
Tabel 2. Hasil Uji Statistik Deskriptif

\begin{tabular}{lrrrrr}
\hline & N & Minimum & Maximum & Mean & Std. Deviation \\
\hline Gender & 79 & 14 & 30 & 23,56 & 3,944 \\
Penghargaan Finansial & 79 & 13 & 30 & 23,53 & 3,250 \\
Pertimbangan Pasar Kerja & 79 & 15 & 30 & 23,80 & 3,048 \\
Minat Berkarir Menjadi Akuntan Publik & 79 & 7 & 30 & 21,37 & 4,677 \\
Valid N (listwise) & 79 & & & & \\
\hline Sumber: Data diolah SPSS, 2021 & 79 & & & &
\end{tabular}

Sumber: Data diolah SPSS, 2021

Pengujian validitas dalam penelitian ini menggunakan tingkat signifikansi sebesar $\alpha=$ 5\%. Pertanyaan kuesioner dikatakan valid apabila $r$ hitung lebih besar daripada $r$ tabel dan nilai signifikansi lebih kecil dari pada alpha $(\alpha) 0,05$. Sebaliknya pertanyaan kuesioner dikatakan tidak valid apabila $r$ hitung lebih kecil dari $r$ tabel dan nilai signifikansi lebih besar daripada alpha $(\alpha) 0,05$. Berdasarkan hasil uji validitas diatas diketahui jumlah indikator pertanyaan sebanyak 24 item pertanyaan dengan sampel sebanyak tujuh puluh sembilan responden, nilai koefisien korelasi " $\mathrm{r}$ " product moment dari person ( $\mathrm{r}$ tabel $=0,2213$ ), sehinga dapat dilihat bahwa hasil uji validitas untuk semua item pertanyaan menghasilkan koefisien $r$ hitung $>r$ tabel yaitu 0,2213 pada taraf sig 5\%. Maka dapat disimpulkan bahwa semua item indikator pertanyaan valid dan dapat digunakan untuk pengujian selanjutnya.

Uji Reliabilitas adalah alat uji yang digunakan untuk mengukur item pertanyaan pada suatu kuesioner yang merupakan alat pengukur variabel. Uji reliabilitas ini digunakan untuk menguji sejauh mana instrumen dapat diandalkan atau dipercaya dalam mengukur variabel. Variabel dikatakan reliabel apabila nilai Cronbach Alpha lebih besar dari 0,60. Berikut ini merupakan hasil perhitungan uji reliabilitas masing-masing variabel:

Tabel 3. Hasil Uji Reabilitas

\begin{tabular}{lccc}
\hline \multicolumn{1}{c}{ Variabel } & $\begin{array}{c}\text { Cronbach } \\
\text { Alpha }\end{array}$ & $\begin{array}{c}\text { Batas Minimal } \\
\text { Cronbach Alpha }\end{array}$ & Keterangan \\
\hline Gender $\left(\mathrm{X}_{1}\right)$ & 0,713 & 0,60 & Reliabel \\
Penghargaan Finansial $\left(\mathrm{X}_{2}\right)$ & 0,735 & 0,60 & Reliabel \\
Pertimbangan Pasar Kerja $\left(\mathrm{X}_{3}\right)$ & 0,602 & 0,60 & Reliabel \\
Minat Berkarir Menjadi Akuntan Publik & 0,904 & 0,60 & Reliabel \\
$(\mathrm{Y})$ & & & \\
\hline
\end{tabular}

Sumber: Data diolah SPSS, 2021

Berdasarkan hasil uji reliabilitas pada tabel 3 diatas dapat dilihat bahwa setiap variabel baik variabel independen (Gender, Penghargaan Finansial dan Pertimbangan Pasar Kerja) maupun variabel dependen yaitu Minat Berkarir Menjadi Akuntan Publik memiliki nilai Cronbach Alpha yang lebih besar daripada 0,060, maka dapat disimpulkan bahwa setiap instrumen tersebut dapat dipercaya dan dapat diandalkan, sehingga item pertanyaan pada penelitian ini dapat digunakan untuk dilakukan uji selanjutnya.

\subsection{Uji Asumsi Klasik}

Pengujian asumsi klasik ini terdiri dari pengujian normalitas, uji multikolinearitas dan uji heterokedastisitas

Data dikatakan berdistribusi normal apabila nilai probabilitas signifikan KolmogrovSmirnov Test lebih besar dari 5\% atau 0,05. Hasil uji normalitas dapat dilihat pada gambar 1 dan tabel 4 sebagai berikut: 


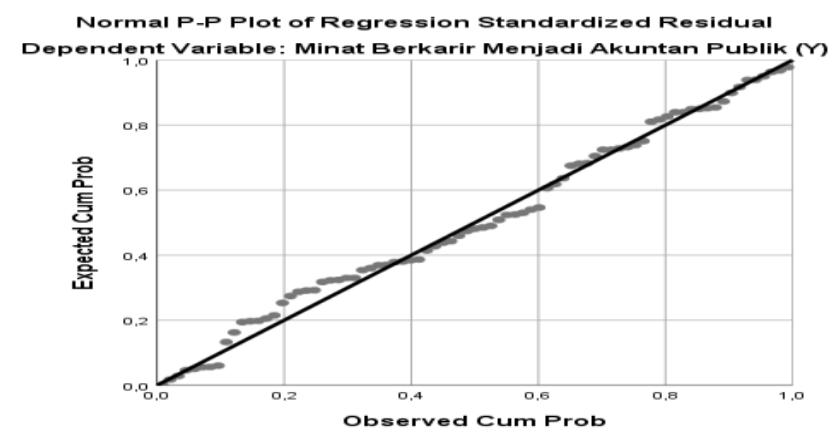

Sumber: Data diolah SPSS, 2021

Gambar 1. Normal Probability plot

Berdasarkan hasil uji normalitas probability plot dapat dilihat pada gambar 1 bahwa pola titik-titik mengikuti garis diagonal dan penyebarannya mengikuti garis diagonal.

Tabel 4 Hasil One-Sample Kolmogorov-Smirnov Test

\begin{tabular}{llr}
\hline & & $\begin{array}{c}\text { Unstandardized } \\
\text { Residual }\end{array}$ \\
\hline $\mathrm{N}$ & Mean & 79 \\
Normal & Std. & 0 \\
Parameters & Deviation & 4,0631584 \\
& Absolute & 0,068 \\
Most Extreme & Positive & 0,06 \\
Differences & Negative \\
Test Statistic & $-0,068$ \\
Asymp. Sig. (2-tailed) & 0,068 \\
\hline a. Test distribution is Normal. &, $200^{\mathrm{c}, \mathrm{d}}$ \\
b. Calculated from data. & \\
c. Lilliefors Significance Correction. \\
d. This is a lower bound of the true significance. \\
\multicolumn{2}{c}{ Sumber: Data diolah SPSS, 2021 }
\end{tabular}

Berdasarkan uji kolmogrov-smirnov pada tabel 4 memperlihatkan bahwa nilai Asymp.Sig (2-tailed) adalah sebesar 0,200 c.d dimana nilai tersebut lebih besar dari $5 \%$ atau 0,05 sehingga dapat disimpulkan bahwa data residual dalam model regresi ini berdistribusi normal dan dapat digunakan untuk analisis selanjutnya. Berdasarkan hasil uji Multikolonieritas didapat bahwa masing-masing variabel menunjukkan nilai tolerance $>0,10$ dan nilai VIF (Variance Inflanation Factor) $<10,00$ Sehingga dapat disimpulkan bahwa seluruh variabel independen tidak menunjukkan adanya gejala multikolinearitas.

Dalam penelitian ini metode yang digunakan untuk mendeteksi gejala heteroskedastisitas adalah dengan menggunakan pendekatan scatteerplots secara grafik dan uji Glejser secara statistik, yaitu memperhatikan plots dari sebaran residual dan variabel yang di preksdiksikan. Apabila nilai signifikansi dari masing-masing variabel independen lebih besar dari 0,05 maka model regresi tersebut adalah homoskedastisitas atau tidak terjadi heteroskedastisitas. Berikut merupakan hasil uji heterokedastisitas: 


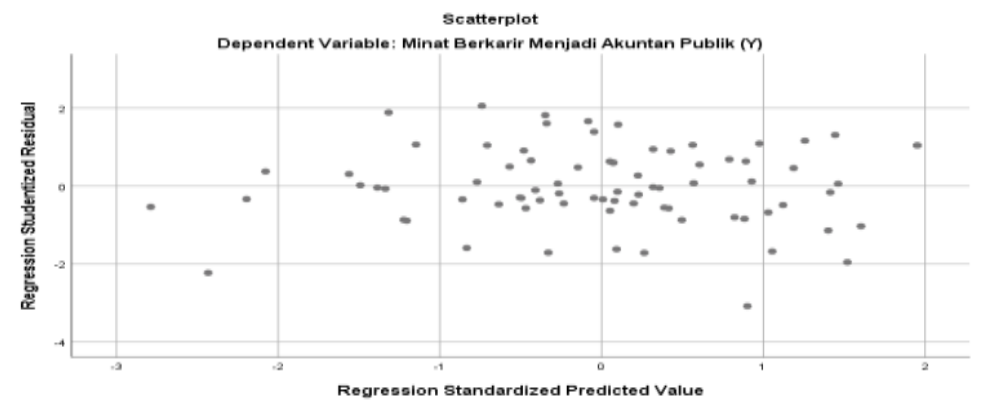

Sumber: Data diolah SPSS, 2021

Gambar 2 Hasil Uji Scatterplot

Berdasarkan hasil uji Scatterplot pada gambar 2 diatas dapat dilihat bahwa titik-titik menyebar secara acak diatas dan dibawah angka 0 dan tidak membentuk pola tertentu, sehingga dapat disimpulkan bahwa tidak terjadi gejala heterokdastisitas. Berdasarkan hasil uji Glejser untuk masing-masing variabel independen lebih besar dari 0,05 sehingga tidak signifikan secara statistik mempengaruhi residual sehingga dapat disimpulkan bahwa tidak terjadi gejala heterokedastisitas.

\subsection{Analisis Regresi Linear Berganda dan Pembahasan}

Analisis regresi linear berganda dilakukan dengan tujuan untuk menguji atau mengukur pengaruh hubungan antara dua atau lebih variabel serta menunjukkan arah hubungan antara variabel bebas (independen) dengan satu variabel tetap (dependen). Penelitian ini menganalisis pengaruh variabel independen yaitu gender, penghargaan finansial dan pertimbangan pasar kerja terhadap variabel dependen yaitu minat berkarir menjadi akuntan publik pada mahasiswa jurusan akuntansi Sekolah Tinggi Ilmu Ekonomi Balikpapan. Variabel dalam penelitian ini diregresi dengan menggunakan bantuan SPSS versi 25. Berikut merupakan hasil regresi linear berganda yang disajikan pada tabel 5 dibawah ini:

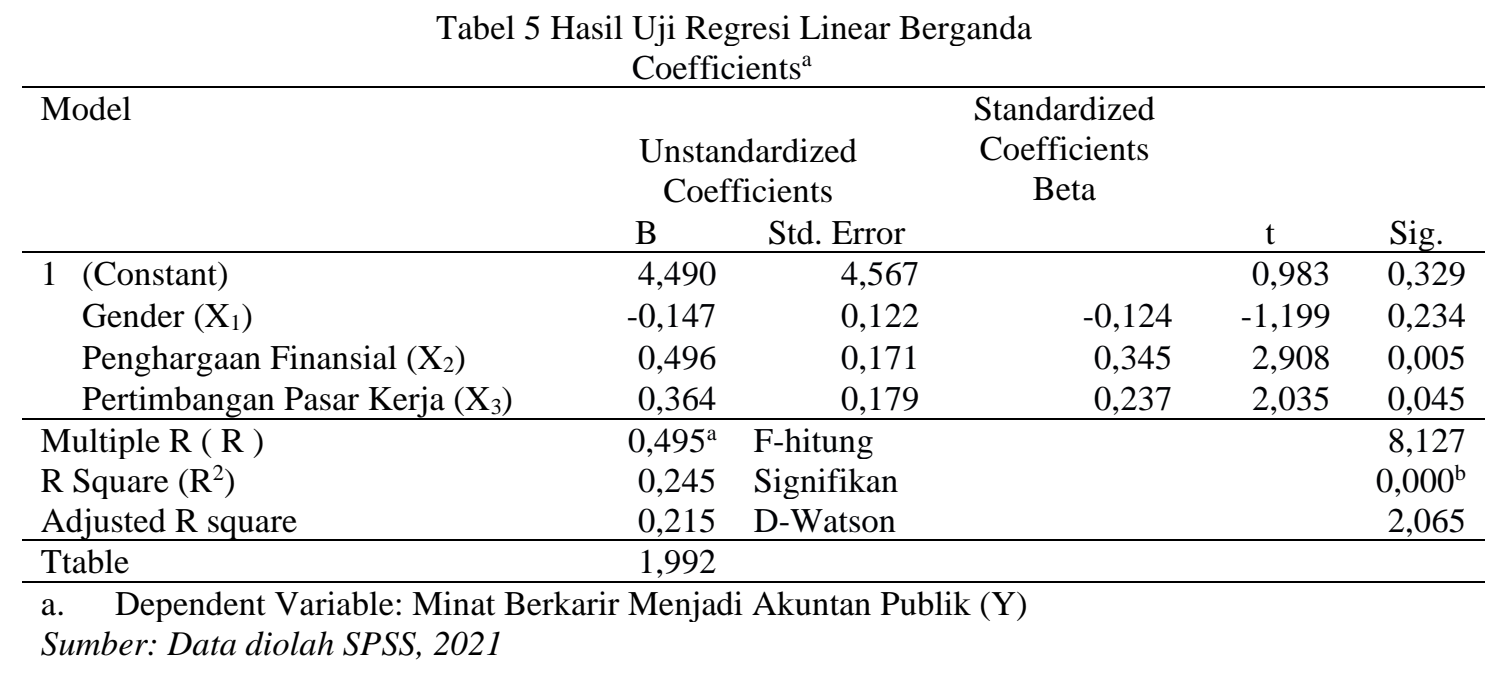


Berdasarkan hasil uji linear berganda pada tabel 5 diatas, maka diperoleh persamaan model penelitian adalah sebagai berikut:

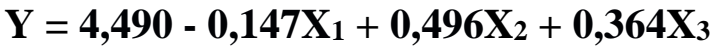

Dari hasil persamaan regresi linear berganda tersebut diatas, maka dapat dijelaskan sebagai berikut:

1. Konstanta

Berdasarkan hasil regresi pada tabel 5 nilai konstanta (a) sebesar 4,490 hal ini menunjukkan bahwa apabila variabel independen atau gender, penghargaan finansial dan pertimbangan pasar kerja konstan atau diasumsikan bernilai nol (0), maka variabel dependen atau minat mahasiswa menjadi akuntan publik akan bernilai positif sebesar 4,490.

2. Koefisien regresi variabel gender $(\beta 1)$

Berdasarkan hasil regresi pada tabel 5 diperoleh bahwa nilai koefisien regresi variabel gender adalah bernilai $-0,147$ sehingga hal tersebut dapat diartikan apabila variabel gender mengalami kenaikan satu satuan, maka variabel minat mahasiswa menjadi akuntan publik akan mengalami penurunan sebesar $14,7 \%$.

3. Koefisien regresi variabel penghargaan finansial $(\beta 2)$

Berdasarkan hasil regresi pada tabel 5 diperoleh bahwa nilai koefisien regresi variabel penghargaan finansial adalah bernilai 0,496 sehingga hal tersebut dapat diartikan apabila variabel penghargaan finansial mengalami kenaikan satu satuan, maka variabel minat mahasiswa menjadi akuntan publik akan mengalami kenaikan sebesar 49,6\%

4. Koefisien regresi variabel pertimbangan pasar kerja ( $\beta 3)$

Berdasarkan hasil regresi pada tabel 5 diperoleh bahwa nilai koefisien regresi variabel pertimbangan pasar kerja adalah bernilai 0,364 sehingga hal tersebut dapat diartikan apabila variabel pertimbangan pasar kerja mengalami kenaikan satu satuan, maka variabel minat mahasiswa menjadi akuntan publik akan mengalami kenaikan sebesar 36,4\%. Pengaruh variabel gender $\left(\mathrm{X}_{1}\right)$ terhadap minat untuk berkarir menjadi akuntan publik pada mahasiswa akuntansi di Sekolah Tinggi Ilmu Ekonomi Balikpapan (Y) ditunjukkan dengan nilai thitung sebesar -1,199 < dari tabel sebesar 1,992 dan nilai sig t sebesar 0,234>0,05 hal ini menunjukkan bahwa untuk variabel gender $\left(\mathrm{X}_{1}\right)$ tidak berpengaruh terhadap minat mahasiswa akuntansi Sekolah Tinggi Ilmu Ekonomi Balikpapan untuk berkarir menjadi akuntan publik. Hasil penelitian ini tidak mendukung hasil penelitian yang dilakukan oleh Dewayani, et al (2017) dan Saputra (2018), yang menyatakan bahwa gender berpengaruh terhadap minat mahasiswa Prodi Akuntansi untuk berkarir sebagai akuntan publik. Dan mendukung hasil penelitian yang dilakukan oleh Suseno (2019), yang menyatakan bahawa gender tidak berpengaruh terhadap minat mahasiswa Prodi Akuntansi dalam berkarir menjadi akuntan publik. Sehingga menolak Hipotesis pertama (H1), yang menyebutkan bahwa gender berpengaruh terhadap minat mahasiswa akuntansi Sekolah Tinggi Ilmu Ekonomi Balikpapan berkarir menjadi akuntan publik. Hal ini bisa dijelaskan bahwa untuk menjadi seorang akuntan publik tidak di dominasi oleh gender atau jenis kelamin, pada waktu satu atau dua dekade yang lalu yang menjadi profesi akuntan publik di dominasi oleh pria, tapi seiring berjalannya waktu maka profesi akuntan publik tidak lagi di dominasi oleh pria. Ini bisa kita lihat di Kantor Akuntan Publik (KAP) sudah banyak kaum wanita yang bekerja disana bahkan pemimpin dari KAP tersebut sudah banyak kaum wanita. Sehingga gender tidak lagi merupakan salah satu faktor yang mempengaruhi lulusan sarjana untuk memilih profesi sebagai akuntan publik.

Pengaruh variabel penghargaan finansial $\left(\mathrm{X}_{2}\right)$ terhadap minat untuk berkarir menjadi akuntan publik pada mahasiswa akuntansi di Sekolah Tinggi Ilmu Ekonomi Balikpapan (Y), ditunjukkan dengan nilai sig t sebesar $0,005<0,05$ dan thitung sebesar 2,908 lebih besar dari table sebesar 1,992 hal ini menunjukkan bahwa untuk variabel penghargaan finansial $\left(\mathrm{X}_{2}\right)$ terbukti berpengaruh terhadap minat mahasiswa akuntansi STIEPAN untuk berkarir menjadi akuntan 
publik. Sehingga menerima hipotesis kedua (H2), yang menyebutkan bahwa penghargaan finansial berpengaruh terhadap minat mahasiswa akuntansi Sekolah Tinggi Ilmu Ekonomi Balikpapan berkarir menjadi akuntan publik. Dan mendukung penelitian yang dilakukan oleh Dewayani, et al (2017) dan Febriyanti (2019, yang membuktikan bahwa penghargaan finansial berpengaruh terhadap pemilihan karir sebagai akuntan pubik. Dan menolak hasil penelitian Trista (2016), yang menyatakan bahwa penghargaan finansial tidak berpengaruh terhadap minat mahasiswa akuntansi dalam berkarir menjadi akuntan publik.

Pengaruh variabel pertimbangan pasar kerja $\left(\mathrm{X}_{3}\right)$ terhadap minat untuk berkarir menjadi akuntan publik pada mahasiswa akuntansi di Sekolah Tinggi Ilmu Ekonomi Balikpapan di tunjukkan dengan nilai thitung sebesar 2,035 > dari tabel sebesar 1,992 dengan nilai sig t sebesar $0,045<0,05$ hal ini menunjukkan bahwa untuk variabel pertimbangan pasar kerja $\left(\mathrm{X}_{3}\right)$ terbukti berpengaruh terhadap minat mahasiswa akuntansi Sekolah Tinggi Ilmu Ekonomi Balikpapan untuk berkarir menjadi akuntan publik. Sehingga menerima hipotesis ketiga (H3) yang menyebutkan bahwa pertimbangan pasar kerja berpengaruh terhadap minat mahasiswa akuntansi Sekolah Tinggi Ilmu Ekonomi Balikpapan berkarir menjadi akuntan publik. Dan juga mendukung penelitian yang dilakukan oleh Dewayani, et al (2017) dan Oktaviani, et al (2020), yang menyatakan bahwa variabel pertimbangan pasar kerja mempunyai pengaruh terhadap minat mahasiswa akuntansi untuk berkarir sebagai akuntan publik.

\section{Kesimpulan}

Berdasarkan hasil penelitian diatas maka dapatlah disimpulkan bahwa dari ketiga variabel bebas yakni gender, penghargaan finansial dan pertimbangan pasar kerja, ada satu variabel yang tidak mempengaruhi yakni gender. Karena sesuai dengan berjalannya waktu maka gender ini tidak lagi menjadi faktor penentu dalam memilih pekerjaan dan ini tidak terkecuali pemilihan profesi menjadi akuntan publik. Dan untuk variabel bebas lainnya penghargaan finansial dan pertimbangan pasar kerja berpengaruh terhadap minat mahasiswa akuntansi Sekolah Tinggi Ilmu Ekonomi Balikpapan untuk menjadi akuntan publik. Variabel yang berpengaruh dominan adalah variabel penghargaan finansial dengan nilai thitung yang paling besar dan t-sig yang paling kecil. Ini juga tidak memungkiri bahwa penghargaan finansial (gaji, insentif dan bonus) merupakan faktor yang sensitif dan dapat mempengaruhi ketertarikan seseorang untuk memilih suatu profesi.

\section{Saran}

Setelah melakukan penelitian, pembahasan dan analisis sampai dengan hasil maka penulis memberikan saran yang dapat digunakan sebagai bahan masukan bagi pihak-pihak yang terkait, yaitu:

1. Bagi pihak perusahaan

Bagi pihak perusahaan yang menggunakan jasa akuntan publik agar dapat lebih memperhatikan permasalahan yang berkaitan dengan penghargaan finansial dan juga pertimbangan pasar kerja, karena dengan diperhatikannya hal-hal tersebut maka akan meningkatkan minat mahasiswa untuk memilih karir menjadi akuntan publik yang profesional.

2. Bagi pihak Sekolah Tinggi Ilmu Ekonomi Balikpapan (STIEPAN)

Agar dapat dijadikan sebagai bahan pertimbangan dalam mendorong minat mahasiswa untuk memilih berkarir menjadi seorang akuntan publik serta mengadakan penjurusan bagi para mahasiswa akuntansi di STIEPAN sehingga dapat membuat para mahasiswa akuntansi memikirkan secara serius sejak masih duduk dibangku kuliah mengenai karir apa yang diinginkan dan akan dijalaninya kelak di masa depan sekaligus membentuk kepribadian yang siap menjadi seorang akuntan publik.

3. Bagi para Mahasiswa Akuntansi

Bagi para Mahasiswa Akuntansi, penelitian ini dapat digunakan untuk menambah pengetahuan dan memperkaya literatur untuk berkarir menjadi seorang Akuntan Publik, 
sehingga diharapkan dengan adanya penelitian ini dapat meningkatkan minat berkarir dibidang akuntan publik, yang mana memiliki peluang karir yang cukup besar.

4. Bagi peneliti selanjutnya

Bagi peneliti selanjutnya yang ingin mengkaji masalah yang sama, diharapkan dapat menambah variabel-variabel lainnya yang mempengaruhi minat mahasiswa akuntansi untuk berkarir menjadi akuntan publik yang tidak dibahas pada penelitian ini seperti variabel lingkungan keluarga, motivasi, lingkungan kerja, personalitas dan pengakuan profesional serta penelitian ini dapat dijadikan referensi untuk penelitian selanjutnya yang berkaitan dengan minat akuntan publik.

\section{Ucapan Terimakasih}

Terimakasi kami ucapkan kepada seluruh civitas akademi STIE Balikpapan yang telah memberikan dukungan sehingga penelitian ini terlaksana dan dapat diselesaikan tepat waktu.

\section{Daftar Pustaka}

Dewayani, M.A, Chasanah, C \& Anam, M. S. (2017). Faktor-Faktor yang Mempengaruhi Mahasiswa Akuntansi dalam Pemilihan Karir menjadi Akuntan Publik. The $6^{\text {th }}$ University Research Colloquium (URECOL), 1-8. http://journal.ummgl.ac.id/index.php/urecol/article/view/740/750

Febriyanti, Fenti. (2019). Faktor-Faktor yang Mempengaruhi Minat Mahasiswa Akuntansi Dalam Pemilihan Karir Sebagai Akuntan Publik. JAK (Jurnal Akuntansi), 6(1), 1-11. https://e-jurnal.lppmunsera.org/index.php/Akuntansi/article/view/1036/885

Gendro,Wiyono. 2011. Merancang Penelitian Bisnis dengan Alat Analisis SPSS 17.0 \& Smart PLS 2.0. Yogyakarta: Percetakan STIM YKPM.

http://ejournal.unp.ac.id/index.php/wra/article/view/8730/6726

Nurhayati, Eti.2011.Bimbingan Konseling \& Psikoterapi Inovatif.Yogyakarta.Pustaka Pelajar. Oktaviani,Y.S., Zoebaedi, F. \& Ami, S.M. (2020). Analisis Faktor-Faktor Yang Mempengaruhi Minat Mahasiswa Akuntansi Berkarir Menjadi Akuntan Publik (Studi Pada Mahasiswa Prodi Akuntansi FEB Universitas Pancasila). Jurnal Relevan, 1(1), 47-59. file:///E:/JURNAL\%20UNTUK\%20L\%20300/JURNAL\%20JSHP\%20POLTEKBA

Puspitawati, Herien. 2019. Gender dan Keluarga: Konsep dan Realita. Bogor. IPB PRESS

Putro, Adi Surono. 2012. "Analisis Faktor-Faktor Yang Mempengaruhi Minat Mahasiswa Akuntansi Untuk Berkarir Menjadi Akuntan Publik (Studi Kasus Pada Mahasiswa Program Studi Akuntansi Fakultas Ekonomi Universitas Negeri Yogyakarta)". Skripsi. Universitas Negeri Yogyakarta.

Rivai, Veithzal \& Ella Jauvani Sagala. 2011. Manajemen Sumber Daya Manusia untuk Perusahaan. Rajawali Pers, Jakarta.

Saputra, A. J. (2018). Pengaruh Minat, Motivasi, Pelatihan Profesional, Gender, Lingkungan Pekerjaan Terhadap Pilihan Karir Akuntan. Jurnal Riset Akuntansi dan Keuangan Dewantara (JAD),.1 (2), 1-10.

http://ejournal.stiedewantara.ac.id/index.php/JAD/article/view/240/178

Sugiyono (2018). Metode Penelitian Kuantitatif, Kualitatif dan R\&D. Bandung: Alfabeta.

Suseno, N. S. (2019). Pengaruh Gender, Motivasi Eksternal dan Internal Terhadap Persepsi Mahasiswa Akuntansi dalam Memilih Karier Sebagai Akuntan Publik. Jurnal Komunikasi Universitas Garut: Hasil Pemikiran dan Penelitian, 4(2), 75-98.

https://journal.uniga.ac.id/index.php/JK/article/view/487/466

Trista, Lona. 2016. "Analisis Faktor-Faktor Yang Mempengaruhi Pemilihan Karir Mahasiswa Akuntansi Dengan Lingkungan Kerja Sebagai Variabel Moderating”. Tesis. Universitas Sumatera Utara. http://repositori.usu.ac.id/handle/123456789/535 